\title{
OPTIMASI KINERJA SUSPENSI UNTUK MENINGKATKAN KENYAMANAN DENGAN VARIASI TEKANAN BAN DAN BERAT PADA KENDARAAN INNOVA 2000 CC
}

\author{
Gunawan ${ }^{1}$, \\ Prodi Teknik Rekayasa Otomotif, Politeknik Keselamatan Transportasi Jalan, Tegal \\ Jl Semeru No. 3 Kota Tegal
}

\begin{abstract}
ABSTRAK
Perkembangan teknologi kendaraan tidak hanya mengurangi tingkat emisi dan tingkat konsumsi bahan bakar saja namun peningkatan kenyamanan kendaraan sangat penting. Kenyamanan adalah parameter utama yang menentukan kualitas kendaraan.Kriteria getaran untuk tubuh manusia berdasarkan standar internasional ISO 2631(1974)dimana kendaraan transportasi dengan frekuensi $1-80 \mathrm{~Hz}$. Salah satu bagian penting kendaraan yang berpengaruh besar terhadap keamanan dan kenyamanan kendaraan adalah sistem suspensi. Setelah dilakukan pengujian nilai amplitudo tertinggi 2,06 dan terendah 1,75. Hasil nilai getaran optimasi sebesar10,780 $\leq \mathrm{Y} \leq 12,220 . \omega=12,57 \mathrm{rad} / \mathrm{s} . \Omega_{\mathrm{n}}=12,7 \mathrm{rad} / \mathrm{s}, \mathrm{f}_{\mathrm{n}}=2,02 \mathrm{H}_{\mathrm{z}}$, rasio redaman $\xi=$ $0,210, \delta=0,163$. Perbandingan amplitudo ini mempunyai standar jika perbandingan frekuensi eksitasi $(\omega)$ dengan frekuensi pribadi $\left(\omega_{n}\right)$ lebih kecil dari $\sqrt{2}=1,414$ maka amplitudo kendaraan bisa lebih besar dari amplitudo eksitasi jalan. Sebaliknya jika harga perbandingan tersebut lebih besar dari $\sqrt{2}=1,414$ maka amplitudo getaran kendaraan lebih kecil dari amplitudo eksitasi jalan, kondisi inilah yang diharapkan pada kendaraan sehingga dampak getaran pada tubuh manusia tidak besar.
\end{abstract}

Kata Kunci : ISO 2631(1974), optimasi,tekanan ban,berat kendaraan,amplitudo.

\begin{abstract}
The development of vehicle technology not only reduces the level of emissions and fuel consumption levels alone but increase vehicle comfort is very important. Convenience is the main parameter that determines the quality of the vehicle. Criteria vibration to the human body based on international standards ISO 2631 (1974) in which the transport vehicle with a frequency of 1$80 \mathrm{~Hz}$. One of the important parts of vehicles which have great impact on the safety and comfort of the vehicle is the suspension system. After testing the highest amplitude value of 2.06 and the lowest was 1.75. Results of the optimization of the value of vibration $10.780 \leq Y \leq 12.220$. $\omega=$ $12.57 \mathrm{rad} / \mathrm{s} . \Omega n=12.7 \mathrm{rad} / \mathrm{s}, \mathrm{fn}=2,02 \mathrm{~Hz}$, damping ratio $\xi=0.210, \delta=0.163$. This amplitude comparison has standard if the comparison frequency excitation $(\omega)$ with the natural frequency $(\omega n)$ is smaller than $\sqrt{2}=1.414$ then the vehicle may be greater amplitude than the amplitude of the excitation path. Conversely, if the price comparison is greater than $\sqrt{2}=1.414$ then the vehicle vibration amplitude smaller than the amplitude of the excitation path, this is the condition expected at the vehicle so that the impact of vibration on the human body is not great.
\end{abstract}

Keywords: ISO 2631 (1974), optimasion, tire pressure, vehicle weight, amplitude 


\section{PENDAHULUAN}

Kenyamanan adalah parameter utama yang menentukan kualitas kendaraan. Salah satu kriteria kenyamanan bagi penumpang kendaraan yang terkena getaran vertikal adalah kriteria Janeway yaitu Society of Automotive Engineering (SAE) yang diwujudkan dalam manual ride and vibration. Kriteria getaran untuk tubuh manusia berdasarkan standar internasional ISO 2631(1974) dimana kendaraan transportasi dengan frekuensi 1-80 Hz. Salah satu bagian penting kendaraan yang berpengaruh besar terhadap keamanan dan kenyamanan kendaraan adalah sistem suspensi. Sistem suspensi berfungsi untuk menyerap getaran yang ditimbulkan oleh kondisi jalan yang tidak rata maupun menjaga stabilitas kendaraan pada berbagai kondisi jalan dalam rangka mereduksi oskilasi pada kendaraan (rolling, pitching, bouncing dan yawing) yang sangat berpotensi menimbulkan kecelakaan. Sistem suspensi terbagi menjadi dua bagian, yaitu sistem suspensi pasif dan sistem suspensi aktif. Sistem suspensi pasif memiliki konstanta peredaman dengan nilai konstan sehingga tingkat kenyamanan berubah mengikuti kondisi permukaan jalan. Sedangkan suspensi aktif merupakan tipe suspensi yang memiiki proses pengendalian. Kinerja suspensi baik pasif maupun aktif sangat ditentukan dari desain, kualitas komponen suspensi, kondisi ban serta komposisi berat kendaraan (masa terpegas dan masa tidak terpegas). Masa terpegas (sprung mass) adalah masa yang ditopang pegas yaitu bodi dan berat (penumpang dan barang didalamnya), sedang masa tidak terpegas (unsprung mass) adalah bagian di bawah pegas yaitu poros ban dan roda.

Analisa dan prediksi dari perilaku dinamik (dynamics behavior) dari sistem suspensi ditandai oleh gerakan vibrasi. Getaran sistem suspensi ini berisolasi terhadap posisi keseimbangan yang mempengaruhi kenyamanan dan keamanan berkendaaraan. Sistem suspensi ini sendiri sangat kompleks untuk dianalisa, disisi lain diperlukan kemampuan untuk memprediksi perilaku sistem suspensi itu sendiri. Pengembangan sebuah model matematis yang diasumsikan memenuhi syarat dalam menggambarkan sistem suspensi dengan banyak derajat kebebasan (multi degree of fredom). Permodelan dinamik merupakan gambaran nyata dari getaran pada kendaraan yang sebenarnya sehingga mudah dalam mempelajarai dan analisis. Obyek dalam penelitian ini adalah mobil kijang innova 2000 cc th 2005, dengan Suspensi depan Double Whisbone, ukuran ban 205/65R15, berat aksel depan $820 \mathrm{~kg}$ dan berat Aksel belakang $1035 \mathrm{~kg}$.

\section{METODE PENELITIAN}

Metode yang digunakan dalam penelitian ini adalah eksperimen dengan mengkombinasikan enam variabel dan lima level serta menggunakan metode Industriel Taguchi. Matrik orthogonal Taguchi digunakan untuk menentukan jumlah eksperimen dan kombinasi yang optimal.

\section{Teknik Pengumpulan Data}

Pengumpulan data dilakukan secara langsung pada saat pengujian dengan menggunakan alat uji suspensi

\section{Alat dan bahan yang digunakan}




\section{Tabel 1. Bahan Penelitian}

\begin{tabular}{|l|l|l|l|l|}
\hline No & Jenis Bahan & Merek & Spesifikasi & Jumlah \\
\hline 1 & Kantong Pasir & & $50 \mathrm{Kg}$ & $\begin{array}{l}6 \\
\text { kantong }\end{array}$ \\
\hline
\end{tabular}

\section{Tabel 2. Alat Penelitian}

\begin{tabular}{|l|l|l|l|l|}
\hline No & Jenis Alat & Merk & Spesifikasi & Jumlah \\
\hline 1 & Unit Kendaraan & $\begin{array}{l}\text { Toyota } \\
\text { Innova }\end{array}$ & $2000 \mathrm{cc}$ & 1 unit \\
\hline 2 & Suspensi Tester & $\begin{array}{l}\text { Beissbarth } \\
\text { TL600 }\end{array}$ & & 1 unit \\
\hline
\end{tabular}

\section{Alat dan bahan}

Bahan yang digunakan:

Kantong Pasir adalah tempat yang digunakan untuk menyimpan barang, tetapi dipenelitian ini saya gunakan untuk menyimpan pasir agar dapat mengetahui pembebanan yang terjadi pada suspensi kendaraan, pada bagian depan dan belakang bila kendaraan diisi penuh dengan penumpang.

\section{Alat penelitian}

Kendaraan yang digunakan adalah satu buah kijang innova 2000 cc. Dimana dilakukan pengujian untuk mengetahui pembebanan yang terjadi pada kendaraan dengan menggunakan suspensi tester. Serta mengoptimalkan kemampuan chasis dengan dilakukan pengujian dengan menggunakan metode Taguchi. Taguchi merupakan pengujian eksperimental dimana untuk mengetahui pembebanan yang sesuai dengan kendaraan.

\section{Kombinasi Faktor dan Variabel yang akan diteliti}

\begin{tabular}{|c|l|c|c|c|c|c|}
\hline Notasi & \multicolumn{1}{|c|}{ Variabel } & $\begin{array}{c}\text { Level } \\
1\end{array}$ & $\begin{array}{c}\text { Level } \\
2\end{array}$ & $\begin{array}{c}\text { Level } \\
3\end{array}$ & $\begin{array}{c}\text { Level } \\
4\end{array}$ & $\begin{array}{c}\text { Level } \\
5\end{array}$ \\
\hline A & Berat sumbu depan (kg) & 820 & 870 & 920 & 970 & 1020 \\
\hline B & $\begin{array}{l}\text { Tekanan ban kanan } \\
\text { depan (psi) }\end{array}$ & 19 & 23 & 27 & 31 & 35 \\
\hline C & $\begin{array}{l}\text { Tekanan ban kiri depan } \\
\text { (psi) }\end{array}$ & 19 & 23 & 27 & 31 & 35 \\
\hline D & $\begin{array}{l}\text { Berat sumbu belakang } \\
\text { (kg) }\end{array}$ & 1035 & 1085 & 1135 & 1185 & 1235 \\
\hline E & $\begin{array}{l}\text { Tekanan ban kanan } \\
\text { belakang (psi) }\end{array}$ & 19 & 23 & 27 & 31 & 35 \\
\hline F & $\begin{array}{l}\text { Tekanan ban kiri } \\
\text { belakang (psi) }\end{array}$ & 19 & 23 & 27 & 31 & 35 \\
\hline
\end{tabular}




\section{Bagan Alur Penelitian}

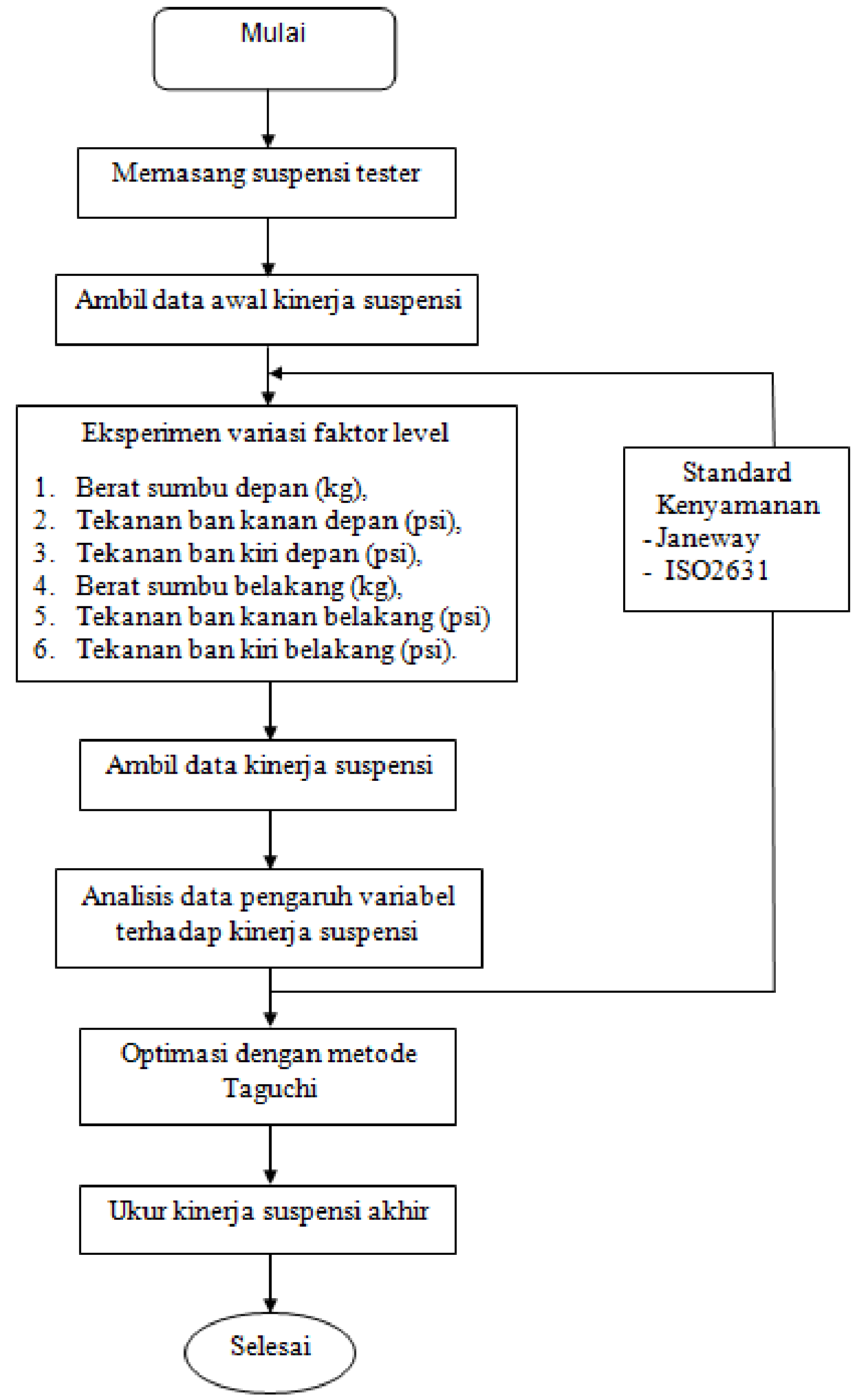

Gambar 3.1 Flowchart Penelitian 


\section{HASIL DAN PEMBAHASAN}

Analisa data pada penelitian ini terdiri dari dua tahap yaitu tahap pengumpulan data dan tahap pengolahan data. Pengumpulan data meliputi kegiatan pembebanan sumbu depan dan belakang serta pemberian tekanan ban depan dan belakang kanan-kiri. Tahap kedua adalah pengolahan data meliputi pengelompokan data analisis variasi, identifikasi faktorlevel, identifikasi faktor-level dominan dan memperkirakan hasil yang optimum.

Faktor dan level setelah dimasukkan ke dalam tabel matrik Taguchi menunjukkan uji kinerja suspensi berdasarkan tabel eksperimen Taguchi dengan 25 kali percobaan, $A, B, C, D, E$, dan $F$ merupakan faktor pengujian sedang tingkat atau level yang akan diuji ditunjukkan pada kolom dan baris dengan ditunjukkan angka 1 sampai dengan 5 yang artinya ada 5 level pengujian. Dari matrik Taguchi di atas diperoleh hasil seperti tabel 4.3 berikut ini:

Tabel 4.3. Matrik taguchi L25(65) array

\begin{tabular}{|c|c|c|c|c|c|c|c|}
\hline Eks & A & B & C & D & E & F & $\begin{array}{c}\text { Hasil } \\
\text { (Hertz) }\end{array}$ \\
\hline 1 & 820 & 19 & 19 & 1035 & 19 & 19 & 15,5 \\
\hline 2 & 820 & 23 & 23 & 1085 & 23 & 23 & 14 \\
\hline 3 & 820 & 27 & 27 & 1135 & 27 & 27 & 14 \\
\hline 4 & 820 & 31 & 31 & 1185 & 31 & 31 & 14 \\
\hline 5 & 820 & 35 & 35 & 1235 & 35 & 35 & 14 \\
\hline 6 & 870 & 19 & 23 & 1135 & 31 & 35 & 13 \\
\hline 7 & 870 & 23 & 27 & 1185 & 35 & 19 & 13 \\
\hline 8 & 870 & 27 & 31 & 1235 & 19 & 23 & 13 \\
\hline 9 & 870 & 31 & 35 & 1035 & 23 & 27 & 13,5 \\
\hline 10 & 870 & 35 & 19 & 1085 & 27 & 31 & 13,5 \\
\hline 11 & 920 & 19 & 27 & 1185 & 35 & 19 & 14 \\
\hline 12 & 920 & 23 & 31 & 1235 & 19 & 23 & 14,5 \\
\hline 13 & 920 & 27 & 35 & 1035 & 23 & 27 & 14,5 \\
\hline 14 & 920 & 31 & 19 & 1085 & 27 & 31 & 13,5 \\
\hline 15 & 920 & 35 & 23 & 1135 & 31 & 35 & 14 \\
\hline 16 & 970 & 19 & 31 & 1235 & 19 & 23 & 16 \\
\hline 17 & 970 & 23 & 35 & 1035 & 23 & 27 & 14 \\
\hline 18 & 970 & 27 & 19 & 1085 & 27 & 31 & 14 \\
\hline 19 & 970 & 31 & 23 & 1135 & 31 & 35 & 14 \\
\hline 20 & 970 & 35 & 27 & 1185 & 35 & 19 & 15 \\
\hline 21 & 1020 & 19 & 35 & 1035 & 23 & 27 & 14 \\
\hline 22 & 1020 & 23 & 19 & 1085 & 27 & 31 & 13,5 \\
\hline 23 & 1020 & 27 & 23 & 1135 & 31 & 35 & 15,5 \\
\hline 24 & 1020 & 31 & 27 & 1185 & 35 & 19 & 13,5 \\
\hline 25 & 1020 & 35 & 31 & 1235 & 19 & 23 & 14,5 \\
\hline
\end{tabular}

Keterangan:

Faktor A : Berat sumbu depan $(\mathrm{kg})$

Faktor B : Tekanan ban kanan depan (psi)

Faktor C : Tekanan ban kiri depan (psi) 
Faktor D : Berat sumbu belakang $(\mathrm{kg})$

Faktor E : Tekanan ban kanan belakang (psi)

Faktor $\mathrm{F} \quad$ : Tekanan ban kiri belakang (psi) sedangkan amplitudonya adalah sebagai berikut :

\begin{tabular}{|c|c|c|}
\hline Ekperimen & Frekwensi(hertz) & Amplitudo \\
\hline $\mathbf{1}$ & 15,5 & 2.06 \\
\hline $\mathbf{2}$ & 14 & 1.88 \\
\hline $\mathbf{3}$ & 14 & 1.88 \\
\hline $\mathbf{4}$ & 14 & 1.88 \\
\hline $\mathbf{5}$ & 14 & 1.88 \\
\hline $\mathbf{6}$ & 13 & 1.75 \\
\hline $\mathbf{7}$ & 13 & 1.75 \\
\hline $\mathbf{8}$ & 13 & 1.75 \\
\hline $\mathbf{9}$ & 13,5 & 1.82 \\
\hline $\mathbf{1 0}$ & 13,5 & 1.82 \\
\hline $\mathbf{1 1}$ & 14 & 1.88 \\
\hline $\mathbf{1 2}$ & 14,5 & 1.94 \\
\hline $\mathbf{1 3}$ & 14,5 & 1.94 \\
\hline $\mathbf{1 4}$ & 13,5 & 1.82 \\
\hline $\mathbf{1 5}$ & 14 & 1.88 \\
\hline $\mathbf{1 6}$ & 16 & 2.12 \\
\hline $\mathbf{1 7}$ & 14 & 1.88 \\
\hline $\mathbf{1 8}$ & 14 & 1.88 \\
\hline $\mathbf{1 9}$ & 14 & 1.88 \\
\hline $\mathbf{2 0}$ & 15 & 2.00 \\
\hline $\mathbf{2 1}$ & 14 & 1.88 \\
\hline $\mathbf{2 2}$ & 13,5 & 1.82 \\
\hline $\mathbf{2 3}$ & 15,5 & 2.06 \\
\hline $\mathbf{2 4}$ & 13,5 & 1.82 \\
\hline $\mathbf{2 5}$ & 14,5 & 1.94 \\
\hline & & \\
\hline
\end{tabular}




\section{spesifikasi kijang innova}

\begin{tabular}{|c|c|c|c|c|c|c|c|c|c|c|c|c|c|}
\hline \multirow{3}{*}{\multicolumn{2}{|c|}{$\begin{array}{l}\text { MODEL / } \\
\text { TYPE }\end{array}$}} & \multicolumn{5}{|c|}{$\mathbf{A} / \mathbf{T}$} & \multicolumn{7}{|c|}{$\mathbf{M} / \mathbf{T}$} \\
\hline & & \multicolumn{2}{|l|}{$\mathrm{V}$} & \multicolumn{2}{|c|}{ G } & \multirow{2}{*}{\begin{tabular}{|c|} 
E \\
$2.0 \mathrm{~L}$ \\
Gasoline \\
\end{tabular}} & \multirow{2}{*}{\begin{tabular}{|c|}
$\mathrm{V}$ \\
$2.0 \mathrm{~L}$ \\
Gasoline
\end{tabular}} & \multicolumn{3}{|c|}{ G } & \multirow{2}{*}{$\begin{array}{c}\mathrm{E} \\
\begin{array}{c}2.0 \mathrm{~L} \\
\text { Gasoline }\end{array}\end{array}$} & \multicolumn{2}{|r|}{$\bar{J}$} \\
\hline & & \begin{tabular}{|c|}
$2.0 \mathrm{~L}$ \\
Gasoline
\end{tabular} & \begin{tabular}{|l|}
$2.5 \mathrm{~L}$ \\
Diesel \\
\end{tabular} & \begin{tabular}{|c|}
$2.0 \mathrm{~L}$ \\
Gasoline \\
\end{tabular} & \begin{tabular}{|l|}
$2.5 \mathrm{~L}$ \\
Diesel \\
\end{tabular} & & & \begin{tabular}{|c|}
$2.5 \mathrm{~L}$ \\
Diesel \\
\end{tabular} & $\begin{array}{c}2.0 \mathrm{~L} \\
\text { Gasoline }\end{array}$ & \begin{tabular}{|l}
$2.5 \mathrm{~L}$ \\
Diesel \\
\end{tabular} & & $\begin{array}{l}2.5 \mathrm{~L} \\
\text { Diesel } \\
\end{array}$ & $\begin{array}{c}2.0 \mathrm{~L} \\
\text { Gasoline }\end{array}$ \\
\hline \multicolumn{14}{|c|}{ DIMENSI / DIMENSION } \\
\hline \multicolumn{2}{|c|}{$\begin{array}{l}\text { Panjang/ } \\
\text { Overall Length } \\
(\mathrm{mm})\end{array}$} & \multicolumn{12}{|l|}{4,585} \\
\hline \multicolumn{2}{|c|}{$\begin{array}{l}\text { Lebar/Overall } \\
\text { Width }(\mathrm{mm})\end{array}$} & \multicolumn{2}{|c|}{1,775} & \multicolumn{3}{|c|}{1,760} & 1,775 & \multicolumn{6}{|c|}{1,760} \\
\hline \multicolumn{2}{|c|}{$\begin{array}{l}\text { Tinggi / Overall } \\
\text { Height }(\mathrm{mm})\end{array}$} & \multicolumn{12}{|l|}{1,750} \\
\hline \multicolumn{2}{|c|}{$\begin{array}{l}\text { Jarak Sumbu/ } \\
\text { Wheelbase } \\
(\mathrm{mm})\end{array}$} & \multicolumn{12}{|l|}{2,750} \\
\hline \multirow{2}{*}{\begin{tabular}{|l|} 
Jarak \\
Pijak \\
Tread \\
\end{tabular}} & $\begin{array}{l}\text { Depan/ } \\
\text { Front } \\
\text { (mm) }\end{array}$ & \multicolumn{12}{|l|}{1,510} \\
\hline & $\begin{array}{l}\text { Belakang } \\
\text { Rear } \\
(\mathrm{mm})\end{array}$ & \multicolumn{12}{|l|}{1,510} \\
\hline \multicolumn{2}{|c|}{\begin{tabular}{|l|} 
Berat kosong \\
$(\mathrm{kg})$
\end{tabular}} & 1.545 & 1.640 & 1.535 & 1.635 & 1.525 & 1.530 & 1.600 & 1.525 & 1.600 & 1.520 & 1.595 & 1.480 \\
\hline
\end{tabular}

\section{Level Faktor Optimum}

Pengaruh tiap-tiap level dan faktor terhadap getaran dapat dilihat pada tabel 4.4 berikut ini.

\section{Tabel 5. Tabel respon dari pengaruh faktor}

\begin{tabular}{|c|c|c|c|c|c|c|}
\hline Level & $\begin{array}{c}\text { A } \\
\text { (Berat } \\
\text { sumbu } \\
\text { depan) }\end{array}$ & $\begin{array}{c}\text { B } \\
\text { (Tekanan } \\
\text { ban } \\
\text { kanan } \\
\text { depan) }\end{array}$ & $\begin{array}{c}\mathrm{C} \\
\text { (Tekanan } \\
\text { ban kiri } \\
\text { depan) }\end{array}$ & $\begin{array}{c}\mathrm{D} \\
\text { (Berat } \\
\text { sumbu } \\
\text { belakang) }\end{array}$ & $\begin{array}{c}\mathrm{E} \\
\text { (Tekanan } \\
\text { ban kanan } \\
\text { belakang) }\end{array}$ & $\begin{array}{c}\mathrm{F} \\
\text { (Tekanan } \\
\text { ban kiri } \\
\text { belakang) }\end{array}$ \\
\hline 1 & 14,30 & 14,50 & 14,00 & 14,30 & 14,70 & 14,20 \\
\hline 2 & 13,20 & 13,80 & 14,10 & 13,70 & 14,00 & 14,40 \\
\hline 3 & 14,10 & 14,20 & 13,90 & 14,10 & 13,70 & 14,00 \\
\hline 4 & 14,60 & 13,70 & 14,40 & 13,90 & 14,10 & 13,70 \\
\hline 5 & 14,20 & 14,20 & 14,00 & 14,40 & 13,90 & 14,10 \\
\hline Selisih & 1,40 & 0,80 & 0,50 & 0,70 & 1,00 & 0,70 \\
\hline Rangking & 6 & 4 & 1 & 2 & 5 & 3 \\
\hline
\end{tabular}

Berdasarkan tabel 4.4 diatas dapat diketahui bahwa kombinasi level faktor untuk mendapatkan getaran terkecil diperoleh pada C3, D2, F2, B4, E3, A2 yaitu tekanan ban kiri depan 27 psi, berat sumbu belakang $1135 \mathrm{~kg}$, tekanan ban kiri belakang 23 psi, tekanan ban kanan depan 31 psi, tekanan ban kanan belakang 27 psi dan berat sumbu depan $870 \mathrm{~kg}$.

Berdasarkan hasil prediksi hasil penelitian yang optimum, kemudian dilakukan uji konfirmasi untuk membuktikan bahwa hasil optimasi berada dalam daerah penerimaan confident interval. Kombinasi level faktor prediksi hasil optimum pada getaran terkecil 
diperoleh pada C3, D2, F2, B4, E3, A2 yaitu tekanan ban kiri depan 27 psi, berat sumbu belakang $1135 \mathrm{~kg}$, tekanan ban kiri belakang 23 psi, tekanan ban kanan depan 31 psi, tekanan ban kanan belakang 27 psi dan berat sumbu depan $870 \mathrm{~kg}$. Hasil percobaan konfirmasi dengan menggunakan kombinasi faktor level optimun adalah sebagai berikut: Rerata Hasil Pengujian

\begin{tabular}{|c|c|c|c|c|c|c|c|c|c|}
\hline A & B & C & D & E & F & Tes 1 & Tes 2 & Tes 3 & Rerata \\
\hline $\begin{array}{c}870 \\
\text { kg }\end{array}$ & 31 & $\begin{array}{c}27 \\
\text { psi }\end{array}$ & $\begin{array}{c}1135 \\
\text { psi }\end{array}$ & $\begin{array}{c}27 \\
\mathrm{~kg}\end{array}$ & $\begin{array}{c}23 \\
\mathrm{psi}\end{array}$ & 12 & 11,5 & 11,5 & 11,67 \\
\hline
\end{tabular}

Berdasarkan tabel diatas menunjukkan bahwa hasil pengujian getaran skala optimasi yaitu bernilai 11,67 yang masih berada dalam interval kepercayaan 10,780 sampai 12,220 berarti hasil uji konfirmasi getaran sebesar 11,67 berada dalam interval penerimaan.

Tabel 5. Hasil perhitungan analisa getaran

\begin{tabular}{|c|c|c|c|c|c|c|c|c|c|c|c|c|}
\hline Eksperimen & $\mathrm{K}_{\mathrm{g}}(\mathrm{kN} / \mathrm{m})$ & $\mathrm{K}_{\mathrm{w}}(\mathrm{kN} / \mathrm{m})$ & $C_{s}(\mathrm{kN} \operatorname{det} / \mathrm{m})$ & $\mathrm{C}_{\mathrm{w}}(\mathrm{kN}$ det $/ \mathrm{m})$ & $K_{e q}(N / m)$ & $\mathrm{C}_{\mathrm{eq}}(\mathrm{N}$ det $/ \mathrm{m})$ & $\omega(\mathrm{rad} / \mathrm{det})$ & $\omega_{n}$ (rad/det) & $f_{n}(H z)$ & $r$ & 5 & $\omega_{\mathrm{d}}(\mathrm{rad} / \mathrm{det})$ \\
\hline 1 & 250 & 150 & 10 & 3.44 & 93750.00 & 2559.52 & 12.57 & 12.70 & 15.50 & 0.99 & 0.24 & 12.31 \\
\hline 2 & 300 & 200 & 20 & 3.68 & 120000.00 & 3108.11 & 12.57 & 14.36 & 14.00 & 0.88 & 0.26 & 13.86 \\
\hline 3 & 250 & 200 & 20 & 3.68 & 111111.11 & 3108.11 & 12.57 & 13.82 & 14.00 & 0.91 & 0.27 & 13.30 \\
\hline 4 & 300 & 150 & 20 & 3.68 & 100000.00 & 3108.11 & 12.57 & 13.11 & 14.00 & 0.96 & 0.29 & 12.56 \\
\hline 5 & 300 & 200 & 10 & 3.68 & 120000.00 & 2690.06 & 12.57 & 14.36 & 14.00 & 0.88 & 0.23 & 13.99 \\
\hline 6 & 300 & 200 & 20 & 3.44 & 120000.00 & 2935.15 & 12.57 & 14.36 & 13.00 & 0.88 & 0.25 & 13.91 \\
\hline 7 & 300 & 150 & 10 & 3.44 & 100000.00 & 2559.52 & 12.57 & 13.11 & 13.00 & 0.96 & 0.24 & 12.74 \\
\hline 8 & 250 & 200 & 10 & 3.44 & 111111.11 & 2559.52 & 12.57 & 13.82 & 13.00 & 0.91 & 0.22 & 13.47 \\
\hline 9 & 250 & 150 & 20 & 3.44 & 93750.00 & 2935.15 & 12.57 & 12.70 & 13.50 & 0.99 & 0.28 & 12.19 \\
\hline 10 & 250 & 150 & 10 & 3.68 & 93750.00 & 2690.06 & 12.57 & 12.70 & 13.50 & 0.99 & 0.26 & 12.27 \\
\hline 11 & 250 & 200 & 10 & 3.68 & 111111.11 & 2690.06 & 12.57 & 13.82 & 14.00 & 0.91 & 0.24 & 13.43 \\
\hline 12 & 300 & 150 & 20 & 3.44 & 100000.00 & 2935.15 & 12.57 & 13.11 & 14.50 & 0.96 & 0.27 & 12.62 \\
\hline 13 & 250 & 150 & 20 & 3.68 & 93750.00 & 3108.11 & 12.57 & 12.70 & 14.50 & 0.99 & 0.30 & 12.12 \\
\hline 14 & 300 & 200 & 10 & 3.44 & 120000.00 & 2559.52 & 12.57 & 14.36 & 13.50 & 0.88 & 0.22 & 14.02 \\
\hline 15 & 250 & 200 & 20 & 3.44 & 111111.11 & 2935.15 & 12.57 & 13.82 & 14.00 & 0.91 & 0.26 & 13.35 \\
\hline 16 & 300 & 150 & 10 & 3.68 & 100000.00 & 2690.06 & 12.57 & 13.11 & 16.00 & 0.96 & 0.25 & 12.70 \\
\hline 17 & 275 & 150 & 10 & 3.44 & 97058.82 & 2559.52 & 13.57 & 12.92 & 14.00 & 1.05 & 0.24 & 12.54 \\
\hline 18 & 275 & 200 & 20 & 3.56 & 115789.47 & 3022.07 & 14.57 & 14.11 & 14.00 & 1.03 & 0.26 & 13.62 \\
\hline 19 & 275 & 200 & 15 & 3.56 & 115789.47 & 2877.16 & 15.57 & 14.11 & 14.00 & 1.10 & 0.25 & 13.67 \\
\hline 20 & 275 & 170 & 15 & 3.44 & 105056.18 & 2798.26 & 16.57 & 13.44 & 15.00 & 1.23 & 0.25 & 13.00 \\
\hline 21 & 275 & 170 & 20 & 3.56 & 105056.18 & 3022.07 & 17.57 & 13.44 & 14.00 & 1.31 & 0.27 & 12.93 \\
\hline 22 & 275 & 150 & 20 & 3.68 & 97058.82 & 3108.11 & 18.57 & 12.92 & 13.50 & 1.44 & 0.29 & 12.35 \\
\hline 23 & 275 & 150 & 15 & 3.44 & 97058.82 & 2798.26 & 19.57 & 12.92 & 15.50 & 1.52 & 0.26 & 12.46 \\
\hline 24 & 275 & 170 & 10 & 3.56 & 105056.18 & 2625.37 & 20.57 & 13.44 & 13.50 & 1.53 & 0.24 & 13.06 \\
\hline 25 & 275 & 200 & 10 & 3.68 & 115789.47 & 2690.06 & 21.57 & 14.11 & 14.50 & 1.53 & 0.23 & 13.73 \\
\hline
\end{tabular}

Hasil $\mathrm{Y}(\mathrm{t})_{1}$ sampai dengan $\mathrm{Y}(\mathrm{t})_{25}$ dapat digambarkan dengan grafik seperti di bawah ini: 


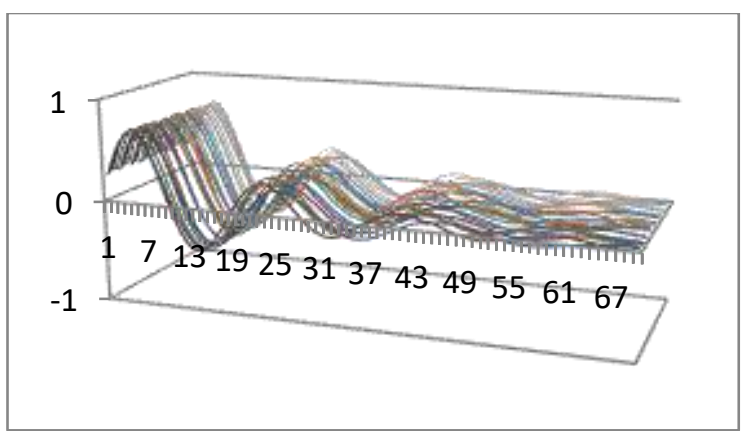

Gambar 1. Persamaan Getaran Paksa dengan Peredaman

Dari 25 eksperimen menunjukan bahwa 4 eksperimen mempunyai nilai frekuensi netral ( $f n$ ) terkecil yang sama, ditunjukan pada gambar1 dan tabel 6 dibawah ini

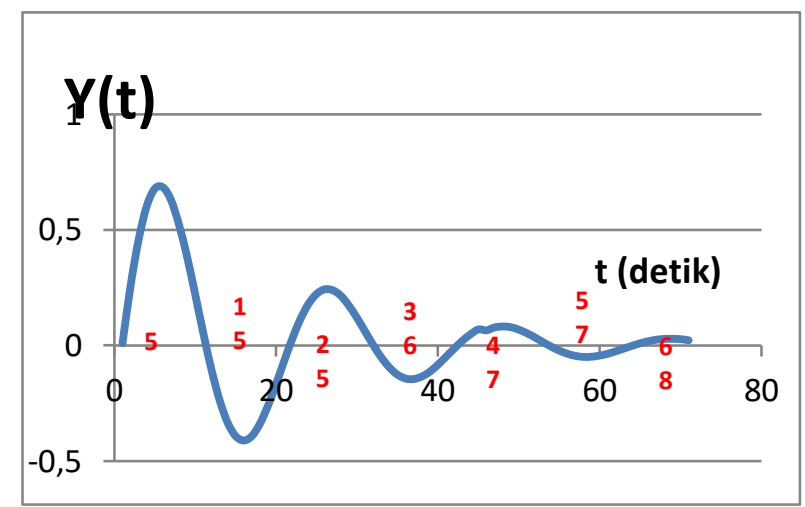

Gambar 6. Persamaan Getaran Paksa Dengan Peredam Eksperimen 1, 9, 10 dan 13

Tabel 7. Persamaan Getaran Paksa Dengan Peredam Pada Eksperimen 1, 9, 10 dan 13.

\begin{tabular}{|c|c|c|c|c|c|c|c|c|c|}
\hline \multirow{2}{*}{ Eksperimen } & \multirow{2}{*}{$\mathrm{Fn}(\mathrm{Hz})$} & \multirow{2}{*}{$\begin{array}{c}\omega_{\mathrm{d}} \\
(\mathrm{rad} / \mathrm{s})\end{array}$} & \multicolumn{7}{|c|}{ Amplitudo Y (t) Pada Waktu (detik) } \\
\hline & & & 5 & 15 & 25 & 36 & 47 & 57 & 68 \\
\hline 1 & 15.5 & 12.7 & 0.6842 & -0.4107 & 0.2433 & -0.1449 & 0.0823 & -0.0490 & 0.0289 \\
\hline 9 & 13.5 & 12.7 & 0.6836 & -0.4073 & 0.2375 & -0.1429 & 0.0794 & -0.0478 & 0.0281 \\
\hline 10 & 13.5 & 12.7 & 0.6840 & -0.4097 & 0.2415 & -0.1444 & 0.0816 & -0.0483 & 0.0286 \\
\hline 13 & 14.5 & 12.7 & 0.6833 & -0.4055 & 0.2387 & -0.1415 & 0.0798 & -0.0470 & 0.0280 \\
\hline
\end{tabular}

Gambar 6 dan tabel 7 diatas menunjukkan bahwa pada eksperimen 9 dan 10 nilai frekuensi pribadi teredam $\left(\omega_{\mathrm{d}}\right)$ dan amplitudo $\left(\mathrm{Y}_{(\mathrm{t})}\right)$ terkecil.

\section{KESIMPULAN}

Berdasarkan hasil pengolahan data dan analisis yang telah dilakukan pada bab sebelumnya, maka dapat ditarik kesimpulan:

1. Berdasarkan identifikasi faktor maka faktor-faktor yang berpengaruh adalah faktor berat sumbu depan (A), tekanan ban kanan depan (B), berat sumbu belakang (D), tekanan ban kanan belakang (E) dan tekanan ban kiri belakang (F).

2. Kombinasi level dari faktor ayng menhasilkan nilai rata-rata dan variasi penurunan getaran untuk kenyamanan berkendaraan yang optimal adalah C3, D2, F2, B4, E3, A2 
yaitu tekanan ban kiri depan 27 psi, berat sumbu belakang $1135 \mathrm{~kg}$, tekanan ban kiri belakang 23 psi, tekanan ban kanan depan 31 psi, tekanan ban kanan belakang 27 psi dan berat sumbu depan $870 \mathrm{~kg}$.

3. Berdasarkan dari percobaan konfirmasi hasil pengujian getaran untuk keamanan dan kenyamanan berada pada interval penerimaan.

4. Jenis shock absorber yang di pakai pada sistem suspensi bagian depan kendaraan ini dengan nilai kekakuan pegas sebesar $250 \mathrm{kN} / \mathrm{m}$, nilai kekauan ban sebesar 150 $\mathrm{kN} / \mathrm{m}$, nilai koefesien peredam suspensi sebesar $20 \mathrm{kN} \mathrm{s} / \mathrm{m}$ dan nilai koefesien peredam ban sebesar $3,68 \mathrm{kN} \mathrm{s} / \mathrm{m}$.

5. Dari 25 eksperimen menunjukan bahwa 4 eksperimen mempunyai nilai frekuensi netral yaitu eksperimen 1, 9, 10 dan 13, eksperimen 9 dan 10 nilai frekuensi pribadi teredam $\left(\omega_{\mathrm{d}}\right)$ dan amplitudo $\left(\mathrm{Y}_{(\mathrm{t})}\right)$ mempunyai nilai terkecil.

\section{DAFTAR PUSTAKA}

Elbani, A. 2012. Kendalian pada Sistem Suspensi Kendaraan dengan Metoda Pole Placement dan Linier Quadratic Optimal Control. Jurnal Elkha, Vol. 4. No.1.

Sutantra, N dan Sampurno, B, 2010, Teknologi Otomotif, Penerbit Guna Widya, Surabaya.

Reimpell J, Stoll H and Betzler JW. 2001. The Automotive Chassis: Engineering Principles. Second Edition, Butterworth-Heinemann, Linacre House, Jordan Hill, Oxford.

Gillespie, TD. 1992. Fundamentals of Vehicle Dynamics. Society of Engineers, Inc, Warrendale.

Wong, J.Y. 1978. Theory of Ground Vehicle. John Wiley \& Sons, New York.

Daryono. 2009. Optimasi Disain Model Pegas Daun Suspensi Kendaraan Dump Truck. Lembaga Penelitian, UMM, Malang.

Susatio dan Biyanto. 2006. Perancangan Sistem Suspensi Aktif pada Kendaraan Roda Empat, Menggunakan Pengendali Jenis Robust Proporsional, Integral dan Derivatif. Jurnal Teknik Mesin, Vol. 8, No. 2.

Karmiadji D.W. 2011. Optimasi Desain Material, Komponen, Konstruksi: Teori Dasar \& Aplikasi. Engineering Clinics FTUP, Jakarta.

Achmad, A. 2002. Rancang Bangun Sistem Suspensi Semiaktif Untuk Peningkatan Kenyamanan Kendaraan. Jurnal Teknik Mesin, Volume 2, Nomor 1

Wibowo, 2011. Perancangan Karakteristik Sistem Suspensi Semi Aktif Untuk Meningkatkan Kenyamanan Kendaraan,Jurnal Teknik Mesin,Volume 10, Nomor 1

Stone, Richer and Jeffrey K. Ball, 2004. Automotive Engineering Fundamentals, SAE Permission 400 Commonwealth Drive, USA 